\title{
EMPOWERMENT AS A QUALITY IMPROVEMENT HUMAN RESOURCES THROUGH THE IMPLEMENTATION OF TOTAL QUALITY MANAGEMENT
}

\author{
Muhammad Ikhsannudin1), Poetri Leharia Pakpahan2) \\ ${ }^{1}$ Fakultas Ilmu Tarbiyah dan Keguruan, Universitas Islam Negeri Sunan Kalijaga Yogyakarta \\ Email: ihsanukhsafi@gmail.com \\ ${ }^{2}$ Fakultas Ilmu Tarbiyah dan Keguruan, Universitas Islam Negeri Sunan Kalijaga Yogyakarta \\ Email: poetrileharia16@gmail.com
}

\begin{abstract}
This paper is a research that examines the empowerment of human resources through the application of total quality management at SMK Miftahul Huda Ngroto Grobogan that this school is always experiencing development and progress according to the times so it is interested to be researched. This type of research uses a qualitative approach, and data collection techniques are through observation and interviews. The research data were presented in a descriptive narrative form. Total quality management is a scientific field that refers to quality, which will improve the quality of human resources in educational institutions, both from educators and students. So as to create superior and competitive educational output. From the results of the research, SMK Miftahul Huda Ngroto Grobogan uses a planned sustainable management system with reference to the total quality management system standard as a basis for empowering human resources to improve quality, so that SMK Miftahul Huda Ngroto is expected to always experience developments based on quality assessment following the times.
\end{abstract}

Keywords: Empowerment, Human Resources, Total Quality Management

\begin{abstract}
Abstrak
Tulisan ini merupakan penelitian yang mengkaji tentang pemberdayaan sumber daya manusia melalui penerapan total quality manajement di SMK Miftabul Huda Ngroto Grobogan babwa sekolah ini selalu mengalami perkembangan dan kemajuan sesuai zaman sehingga tertarik untuk diteliti. Jenis penelitian menggunakan pendekatan kualitatif, dan teknik pengumpulan data yaitu melalui observasi dan wawancara. Data hasil penelitian disajikan bentuk deskriptif naratif. Total quality management merupakan bidang keilmuan yang mengacu pada mutu, yang akan meningkatkan kualitas sumber daya manusia pada lembaga pendidikan baik dari tenaga pendidik maupun peserta didik. Sebingga tercipta output pendidikan yang unggul dan mampu bersaing. Dari hasil penelitian, SMK Miftabul Huda Ngroto Grobogan menggunakan sistem manajemen yang berkelanjutan terencana dengan acuan standar system total quality management sebagai dasar pemberdayaan sumber daya manusia untuk meningkatkan mutu, sebingga SMK Miftabul Huda Ngroto dibarapkan selalu mengalami perkembangan yang berbasis pada penilaian mutu mengikuti perkembangan zaman.
\end{abstract}

Kata kunci: Pemberdayaan, Sumber Daya Manusia, Total Quality Management

\section{INTRODUCTION}

Human Resources often develop not in accordance with the stated goals. Education if seen through the perspective of human capital Theory like using the initial or main concept of education is human, education face a problem that is the lack of application of development of human 
resources potential (under investment in human capital), as the impact of education has not shown a measurable rate of return from the number of graduates entering the global world of work.(Buniarto, 2015) The average education still uses a long or monotonous system, which is still seen as a burden that must be carried out not based on innovation and creative work professionally, so that the achievement of being a quality is very far from the purpose of education (Ismail et al., 2020; Warti'ah, 2020). Therefore, human resources are the most important component that must be prioritized in the progress of education, and there must be improvements, namely improvement efforts through the empowerment of human resources.

Empowerment of human resources is often carried out when the program reaches the desired target, it is not carried out consistently continuously, so that the impact is that when there is no empowerment program, existing human resources will tend to be negligent and return to the initial system. To fix this problem, the consistency of empowerment activities to improve the quality of human resources is always maintained, namely by implementing total quality management in educational institutions (Septiadi, 2019). TQM is an education quality assurance program as a measure of the success of an organization, which is used as a tool for evaluating the work of educational institutions to make continuous improvements (Nurulloh et al., 2020). As part of the components of the human organization it is considered to have an important role in the progress of education, HR must be able to create expertise, be innovative, creative, active in all organizational activities, be able to plan concepts that are carried out in a professional and quality manner, and be responsible (Anwar, n.d.). Therefore, to create a credible organization, it is necessary to establish quality-standard human resources as an effort to improve the quality of human resources.

The quality of human resources can be formed through continuous empowerment in the form of trainings, seminars, workshops, the accuracy of job placements and work responsibilities until a good work culture is formed. As expressed by Widiansyah, quality products will be created by implementing an organizational culture that always prioritizes the quality of its human resources. Therefore, a development in the empowerment of human resources in educational institutions is very appropriate, namely by applying the concept of a sustainable Total Quality Management which is planned continuously for the success of educational institutions (Widiansyah, 2018). In the application of 
Total Quality Management (TQM), develop gradually. These stages include: inspection, quality control, quality assurance, quality management, total quality management, learning organization, then world-class organizations. (world-class organization) (Hanik, 2011). Therefore, in developing Human Resources so that their implementation is in line with what is expected, educational institutions should prioritize quality aspects in the implementation of the education system.

A Quality of priority in the educational system is the main goal that must be implemented in schools, the existence of good quality education will get customer trust. The implementation of total quality management in educational institutions has proven to be a major contribution to achieving quality goals (Supardi, 2018). Quality goals, not only prioritizing a lot of graduate output but also prioritizing graduates who have high competitiveness and are beneficial to society. The empowerment process with continuous improvement includes: empowerment of human resources, from the process of planning, development and job appraisal.(Edwin A. B., n.d.) According to Sudarsono, the main components in the education system which continuously need assessment and development are: 1) Students as basic input, 2) Educators and education personnel as elements of the management of the teaching and learning process, including the Principal, 3) Educational programs curriculum along with input tools as input instruments (Abdullah, n.d.). The achievement of quality priorities in education will have a positive impact on customer satisfaction and will gain the trust of many customers.

Customers in the scope of education are: External customers, consisting of: primary customers (main target group: students) secondary customers (society, government, parents of students who finance), and tertiary groups (other parties who take advantage of the results of education at the school concerned). Meanwhile, internal customers are: (teachers, librarians, laboratory assistants, leaders, administrative and technical employees) (Saril., n.d.).

Since its establishment, SMK Miftahul Huda has committed to be an organizer of superior and quality Islamicbased educational institutions. SMK MIFDA is a boarding school-based school whose education implementation is based on Islamic values, since its establishment as a new school, it has always prioritized empowering human resources to become quality, either done by the school principal himself or in collaboration with experts from higher education. The proof of this commitment was achieved by SMK Miftahul Huda in the four years since its 
establishment was able to obtain the predicate of superior accreditation.

Before this school experienced a level of quality and excellence like now, there were many shortages and not many students were interested in the Miftahul Huda Ngroto Vocational School. So that this school is very interesting to study about its progress through a planned sustainable management system to improve the quality of the school.

\section{DISCUSSION}

The study of total quality management and human resources have been researched by many authors, such as research by Rushaedi Thaheri (2018) on the implementation of TQM to improve the performance of HR elements, Edwin Agus Buniarto (2015), Application of total quality management in improving human resources. Miftahul Munir (2018) The existence of total quality management in educational institutions, Radit Hijrawan, (2019) Development of Human Resource Management Based on Total Quality Management at Madrasah Aliyah Nurul Ummah Kotagede Yogyakarta

Rushaedi thaheri's research, the obsession of education quality based on total quality management comes from input which includes recruitment as well as selection and output includes student screening and tests to measure quality. The key to the successful adoption of total quality management is how the academic management of human resources by addressing service or service as the main quality maximizes organizational competitiveness through continuous improvement of products, services, people, processes, and the environment.

Miftahul Munir's research states that total quality management can be applied in educational institutions if the human resources are consistent to work hard related to integration and employee loyalty to instill quality in their duties. The big role of education requires a great deal of effort in developing education, high quality education can produce reliable and moral human resources.

Edwin Agus Buniarto's research, professional human resource management will create a balance between the needs and the demands and capabilities of an organization, an absolute step to obtain it, namely by improving quality, not only taking refuge in a name. Total quality management is developed not only to emphasize the concept of quality of production but also to prioritize the quality of processes, environment and human resources who are able to produce service products desired by customers.

Radit Hijrawan's research, creating total quality is much easier said than applied. The implementation of TQM demands fundamental changes and changes 
to the traditional organizational culture. To succeed in implementing TQM, organizations need to make changes in leadership behavior and human resource management practices that have various problems such as: focusing on short-term goals, tend to be arrogant, not focused on customers, look down on potential contributions of employees, assume that better quality is only can be achieved at a high cost and prioritizes bossmanship rather than leadership (Radit Hijrawan, n.d.).

\section{Empowerment of Human Resources}

Empowerment of human resources is an aspect of management development, because human resources are a force for other resources in management. If humans cannot provide resources to other management resources, it will be ensured that management in the organization will not be effective, efficient and economical. In cases like this, HR empowerment requires good HR management, namely by implementing a human resource management system which includes a planning process for input to output which includes recruitment, selection, development, and consistency in maintaining the quality of service.(Rushaedi Thahari., 2018) Departing from the foregoing, it can be seen that; Empowerment of human resources is part of an effort to maximize competitiveness with continuous improvement to obtain optimal value or quality (Cahyo, 2017).

Empowerment comes from the word "power" which means "capable". According to Wrihatnolo and Dwidjowito, empowerment can be defined as the process of building people, through developing abilities, changing behavior, and organizing. Empowerment is the giving of responsibility and authority from superiors by involving information and knowledge systems in directing employees (Rokhman., 2003). According to (Wibowo., 2007) that is an effort to make human resources more responsible for what he does.

Meanwhile, Human resources are the potential to use their thoughts and works to be used optimally for the success of an individual or organization after this potential is developed (Notoatmodjo, 1992). Then empowerment of human resources according to Clutterbuck, which is a provision of enthusiasm for work and giving flexibility to the responsibilities that will be carried out by means of improvements that will be made to make a full contribution to the goals of the organization (M Kadarisman., 2006).

Based on some of the explanations above, it can be concluded that human resource empowerment is a development system that is given to increase the responsibility given by optimizing the skills possessed by humans or employees. 
Therefore, empowerment is not only limited to forming individuals through existing procedures for organizational purposes but also increasing creativity awareness of what they have to carry out their given responsibilities in an innovative and efficient manner.

\section{Stages of Human Resource Empowerment}

According to Ambar Tegus S, there are stages that must be carried out in human empowerment. These stages include: Awareness, transformation of abilities, and increasing intellectual abilities (Ambar Teguh, 2004): 1) Awareness stage and behavior formation Forming behavior to become aware of behavior, in order to increase awareness and concern for the need for self-improvement. 2) Ability upgrade transformation stage. The basic principles of knowledge insight, as well as insight into skills in order to open the knowledge that is owned to be developed and to clarify the idea of participating fairly in implementing the basic skills that are used as the development of organizational goals. 3) The stage of increasing intellectual abilities. Intellectual enhancement is the formation of intellectual knowledge for the realization of innovative abilities and initiatives in the independence of relevant thinking. The existence of stages of human resource empowerment aims to establish good quality, so to achieve this goal in the empowerment stage it is implemented with quality assurance or total quality management formulated by Deming.

\section{Total Quality Management Concept}

The basic philosophy of TQM is the prevention of defects, to establish quality control. In quality control, TQM focuses on people, from forming a team to empowering employees (employee empowerment) (Taufiq Rahman., 2013). Human resources are active elements, while other elements are passive elements that can be changed by human creativity (Purwaningsih., 2019). Therefore, empowerment of human resources through TQM is expected to optimize the potential that is owned in order to support the formation of quality education.

Total Quality Management. According to Ishikawa, it is defined as a combination of all functions of the company into a holistic philosophy that is built on the concept of quality team work (Muzayyin Arifin., 2011). Meanwhile, according to Tjiptono, TQM is an approach in running a business that tries to continuously maximize the production of services, people, processes and the environment.(Djam'an Satori., 2008) Sallis, describes " $\mathrm{T}$ " as a total which means involving all people and everything in a comprehensive and integrated organization in a continuous improvement effort. "Q" as quality which means total customer 
satisfaction both externally and internally, while "M" means management which means all people in the organization regardless of their position, position and role are managers in carrying out their responsibilities (Fandy Tjiptono., 2001).

According to the explanation of the scientists, Total Quality Management is a concept of improvement that is consistently integrated to the growth of quality by involving everyone in educational institutions to meet customer demands.

According to Deming, the quality / quality includes conformity between the product and consumer demands, while the quality must be more than the demands, the quality / quality in application in its implementation is related to customer satisfaction.(Daniel C Kambay., 2004) According to Deming, the quality assurance cycle is Plan, Do, Check, Action, or what is popularly known as a concept (PDCA) (Ridwan Abdullah Sani dkk., 2015) Further explanation of the PDCA concept as follows:

Plan is a planning activity to identify process objectives that will be the basis for action, the process includes setting performance standards, expertise experience, and standards of work results. If in educational institutions the determination of work and work experience standards, namely teaching staff or teachers, as well as standard work results include the learning output of students.

Do/Implementation in doing work that has been arranged in planning, including processes in education or work processes, which are carried out with teacher performance standards set by the school, aims to achieve learning experiences and the results of learning carried out by students.

Check/ Evaluation is an effort to recheck the work that has been carried out in the activity process with predetermined standards, is it in accordance with the standard, are there any deficiencies that need to be followed up.

Action/Follow-up, is an activity to follow up in making improvements based on the results of evaluation or checking of the implementation of activities (Rifka Arfeinia dkk., 2020).

Meanwhile, in general, total quality management is a quality control approach through the growth of active participation by members of the organization from small groups with limited work experience to the responsibility of each member, in implementing TQM as a human development approach, not a human use approach (Veithzal Rival Zainal, 2016). Total quality management is an approach and offers a simple concept of how institutions can compete and excel in the competition and produce the best quality 
among existing institutions.(Syam Syam, 2017) To be able to produce the best quality, it is necessary to continuously and continuously improve human resources (Suhermanto, S., Anshari, 2018). In addition, the concept of total quality management also has characteristics, namely oriented to the satisfaction of customer needs and long-term achievement.(Hijrawan, 2019)

Characteristics of Total Quality Management 1) Active participation from all parties, both leaders and members. 2) Quality oriented based on customer satisfaction. 3) Management dynamics, top down and bottom up. 3) Instill a culture of team work well. 4) To instill a culture of problem solving through the PDCA concept (Plan-DO-Check-Action) approach well. 4) Continuous improvement as a problem-solving process in TQM.

Based on the characteristic elements of the application of TQM in education, humans are the main role in the implementation of education management, and humans will also become educational management instruments to become qualified. So it is necessary to empower human resources that is carried out continuously.

Tabel. 1. characteristic elements of the application of TQM in education

\begin{tabular}{ll}
\hline \multicolumn{1}{c}{ Indicator } & \multicolumn{1}{c}{ Implementation of TQM } \\
\hline Input Standard & Planning carried out in the empowerment of the human \\
& resources of Miftahul Huda Vocational School includes: HR \\
& mapping, prediction / forecase of HR needs, HR \\
& implementation by establishing a quality assurance team, and \\
& establishing HR quality standards based on Islamic values. \\
The empowerment of Miftahul Huda Vocational School \\
human resources includes: \\
1. Recruitment, in the recruitment which prioritizes the \\
field of scientific expertise and knowledge of the Islamic \\
religion, not fully based on the stratum of higher \\
education graduates \\
2. Conduct training and scientific development by experts \\
from universities. Managers provide access and \\
motivation for students to continue their undergraduate \\
education studies \\
3. Collaborating with higher education institutions in \\
educational development. \\
4. Conduct monitoring and evaluation of deficiencies to \\
make improvements and make it possible to transfer \\
positions. \\
5. Assistance to teachers who are lacking in mastery of
\end{tabular}




\section{technology,}

Output

Renewal standard
Empowerment of human resources at SMK Miftahul Huda

Ngroto is running well, namely by the formation of a quality assurance team consisting of 10 people, existing human resources consist of young santri who have high scientific loyalty, both in the fields of scientific expertise and religious knowledge. Islam.

1. Increase local wisdom and excellence in the surrounding area by implementing education that is appropriate and needed by the surrounding community.

2. Optimizing the use of technology in the provision of education which includes marketing, employee recruitment, fingerprint attendance systems, learning systems and assessment filling.

3. Optimizing human resources in the use of digitalization learning system technology, through Miftahul Huda TV, and YouTube.
Research on the discussion of human resources, many of which have already done, will only be based on the concept of human resource management in education management, or research on total quality management in global management of educational organizational problems, this study will discuss where there is a link between human resource empowerment and total quality management. Where the concept of total quality management affects the formation of the quality of human resources. Likewise, SMK Miftahul Huda Ngroto Gubug Grobogan which is based on a boarding school which is unique in the formation of its human resources, namely by integrating quality Islamic values so that not only quality, superior but also moral human resources are created.

\section{METHOD}

This study uses a descriptive qualitative research approach with a planned field study to understand a social phenomenon under study (Sugiyono., 2017). Namely the phenomenon of empowering human resources in improving quality through total quality management at SMK MIFDA Gubug, Grobogan. In the description using descriptive qualitative, namely by describing the state of the school, problems, attitudes, opinions, conditions, factually and accurately. (Soewadji Jusuf., 2012). The selection of information as a data source in this study is based on the principle of the subject who 
controls the problem, namely the principal and the Head of the MIFDA Vocational High School quality assurance, as well as the teaching staff. Namely the sampling technique with certain considerations. This means that these sources are the most expert in the information we expect.

The research procedure carried out by researchers is by school field observations. Observation is a complex process composed of various biological and psychological processes (Lexy J. Moleong., 2014). Interviews were conducted to collect data using structured and unstructured interview techniques through face to face face to face and online.(Suharsimi Arikunto., 2010) Further data collection was carried out using an online system because of the Covid 19 pandemic. Then the results of the interviews and the data were taken by research analysts. According to Miles and Humber, the activities in data analysis are carried out interactively and continuously completely by means of: Data Reduction, Data Presentation and Drawing Conclusions/Verification (Sugiyono., 2013).

\section{DISCUSSION}

SMK Miftahul Huda Ngroto was founded in 2015, located on Jalan Kauman No. 10 A, Ngroto, Gubug, Grobogan Regency. The education system is based on Islamic boarding schools, the values of Islamic teachings are always integrated with the learning system, both teaching staff and subjects and the implementation of learning. The curriculum used by SMK Miftahul Huda is a collaborative curriculum between the K13 national education curriculum and the pesantren education curriculum (Budi., 2015).

Based on interviews with the principal, Mr. Yudo Sulistyo, namely SMK Miftahul Huda, every year has increased both in terms of the number of students and the number of teaching staff, because the increase is due to the quality implemented in education at SMK Miaftahul Huda Ngroto, Grobogan.(Yuda Sulistyo., n.d.) Evidence of the increase as described in the diagram as follows: 


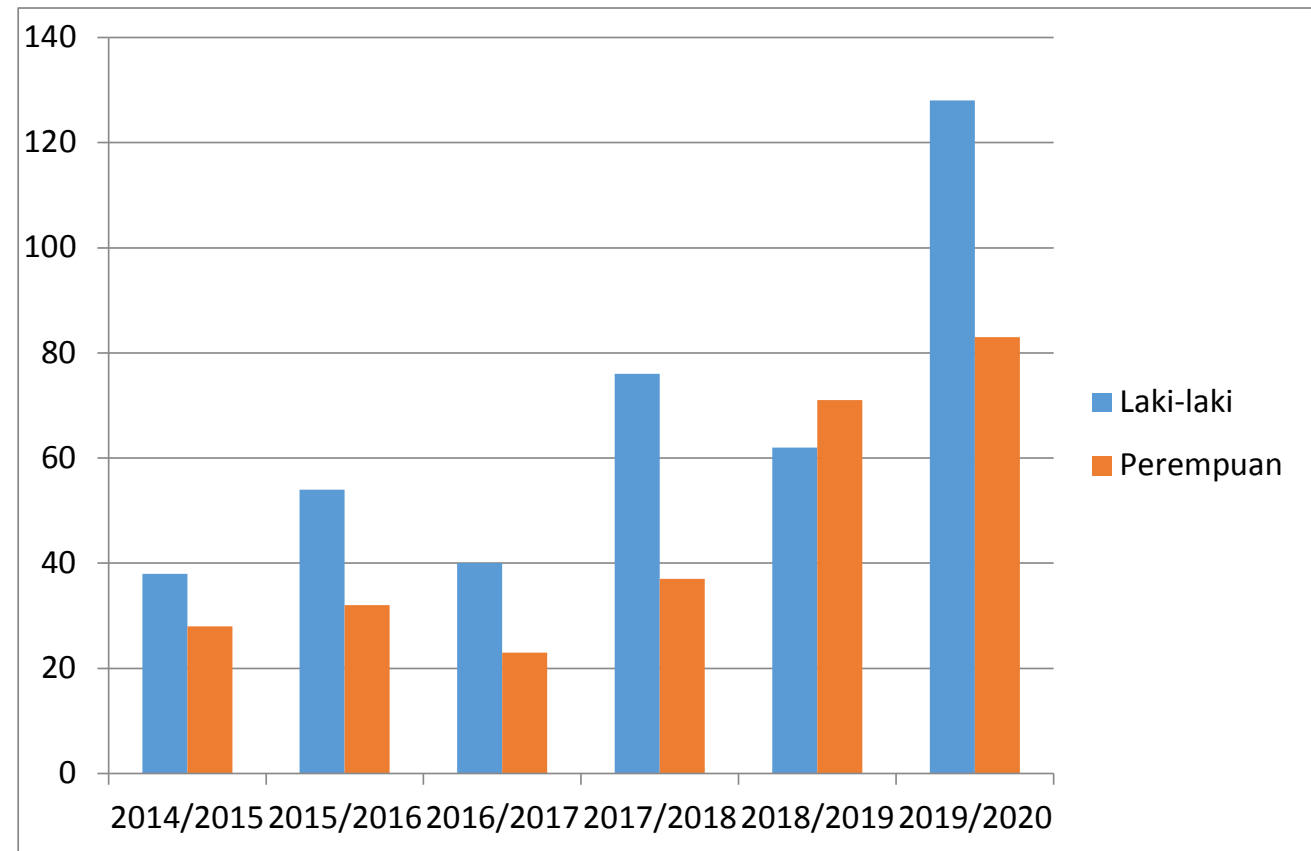

Figure. 1. Education Implemented in SMK Ngroto

The diagram above illustrates the development of students from the beginning of the 2014/2015 academic year to the 2019-2020 academic year as a whole in every year it always increases.(Deni., n.d.) This increase was also offset by the opening of new majors, which originally consisted of two departments of Light Vehicle Engineering and Tatabusana, in the 2017/2018 school year a new department was opened, namely TKJ. And will continue to reopen other new majors. According to the principal, SMK Miftahul Huda from its first graduates immediately got first place at the sub-district level, ranking 1 to 10 was achieved by SMK Miftahul Huda Ngroto students. This achievement, however, cannot be separated from the professional role of institutional managers and educators in being committed to creating quality education. The following is the data for the management and teaching staff of SMK Miftahul Huda Ngroto:

Tabel. 2. Quality Education in Ngroto

\begin{tabular}{llcc}
\hline NO & Information & Teacher & Manager \\
\hline $\mathbf{1}$ & Man & 38 & 1 \\
$\mathbf{2}$ & Women & 15 & 9 \\
& Total & 53 & 10 \\
\hline
\end{tabular}

In an effort to get quality and quality human resources to achieve the goals of educational institutions, SMK Miftahul Huda formed a quality assurance team in empowering human resources through 
empowerment stages, as stated by Najib, the Head of Quality Assurance, according to what was expressed by Ambar Teguh consisting of three stages include: Awareness, transformation of abilities, and improvement of intellectual abilities.(Ambar Teguh, 2004)

\section{Stages of Awareness}

SMK Miftahul Huda has undergone many developments and reforms in the direction of improving better quality. This significant development is not achieved without the continuous empowerment. According to school principal Yuda Sulistyo, empowerment is primarily carried out, namely by raising awareness of what she has in her to develop effective and innovative human resources in carrying out their responsibilities, as well as making work administration standards (Yuda Sulistyo., n.d.).

The awareness stages carried out at SMK Miftahul Huda Ngroto are: carried out by the principal including, first of all, awareness which is carried out by cultivating an attitude that is born of oneself / internal, which includes 1). Providing work awareness stimuli, his work and will reflect on him, 2). Cultivate an attitude of responsibility, 3). Understand his position in his work, 4). Growing work as a hobby in his life. Second, awareness from outside oneself/externally which includes awareness of human resources through assessment of administrative standards on the capabilities of human resources at SMK Miftahul Huda Ngroto. These standards include 1). Recruitment according to their field expertise and minimum expertise in religious knowledge, including: Al-Qur'an reading skill, monotheism, and moral knowledge, 2) Assessment of training conducted by the school and by other parties outside the school, 3). Identify the planning ability of each member according to their field, of course, in teacher education institutions they are required to be able to develop lesson plans to make changes (Muhammad Najib., 2020).

This awareness is carried out continuously to form a work culture, starting from the competencies possessed, performance skills and work enthusiasm. Awareness is carried out by the school principal not only at work evaluation meetings but is more inculcated for each member to actively participate in raising awareness for members (reprimanding each other, and helping each other).

\section{Ability Transformation Stages}

In this stage, the basic skills that are owned will be developed to clarify the competence of the expertise that is owned. As stated by Jim, in human empowerment, 
namely providing full resources in determining his future, between opportunities, knowledge, and skills to improve abilities (Chairul Muhammad., n.d.).

According to the Head of Quality Assurance, Muhammad Najib, in improving the quality of abilities, namely by holding seminars and training. Training at SMK Miftahul Huda Ngroto is held starting from HR recruitment to job placement, seminars and training are guided directly by the principal, sometimes also bringing in experts from outside the school, usually collaborating with UNES, in addition to training held at school also following trainings held by the Education and Culture Office, and the Vocational Training Center (BLK). In improving the ability at SMK Miftahul Huda, it also always provides assistance for new members, the assistance is carried out by the quality assurance team, and members who are already experts in their fields, for example:(Muhammad Najib., 2020)

This is done to get the quality of educators and education personnel who are superior and have good character. Through this training program, new employees will receive material from the instructors, so that they can adapt to the organizational culture at SMK Miftahul Huda Ngroto and continue to hone and improve their competencies and skills, according to the expectations of the institution.

\section{Stages of Increasing Intellectual Ability}

Based on the results of research conducted at SMK Miftahul Huda Ngroto, in improving intellectual abilities, namely by having regular trainings, as well as growing work awareness in carrying out responsibilities continuously. With the existing human resource training at SMK Miftahul Huda Ngroto, it has significantly experienced intellectual development, in the form of implementing skills in improving the quality of education at SMK Miftahul Huda Ngroto.

Yuda Sulistyo, Head of School, Miftahul Huda Vocational High School, said that in four years of holding the Miftahul Huda Vocational School education, it can achieve Superior Accreditation, and get the best graduate ranking at the sub-district level so that graduates can be accepted in public and private universities including, UNES, UIN Walisongo, UNISULA, and UNWAHAS. This can be achieved because of the implementation of morale carried out by all levels of education who work together hard to create good quality education, and have the hope of becoming a pilot school, especially for other schools based on 
pesantren, as well as schools in general. According to the principal, to further improve the quality of the school, the ranks of SMK do not stop and are satisfied with the results achieved.(Yuda Sulistyo., n.d.)

To improve the intellectual quality of Educators and Education Personnel who join SMK Miftahul Huda, they are included in training activities, workshops and so on on a regular basis, the aim of which is to improve the ability to always think creatively and innovatively on their skills.

In the intellectual development of human resources, the school also provides opportunities for educators and education staff to continue their studies to the next higher stage, in order to improve their respective knowledge, competencies and skills. In this case, the school always provides motivation and access for educators who do not have an S1 certificate to continue their education.

The following is a table of quality assurance at SMK Miftahul Huda Ngroto, Grobgogan based on an interview with the Quality Assurance Team: (Muhammad Najib., 2020)
Tabel. 3. Quality Assurance in SMK Miftahul Huda

\begin{tabular}{|c|c|}
\hline $\begin{array}{c}\text { Quality } \\
\text { assurance }\end{array}$ & HR empowerment \\
\hline Plan / planning & $\begin{array}{l}\text { Long-term planning, } \\
\text { through } \\
\text { empowerment stage }\end{array}$ \\
\hline $\begin{array}{l}\text { Do } \\
\text { Implementation }\end{array}$ & $\begin{array}{l}\text { Woark team culture, } \\
\text { / family culture }\end{array}$ \\
\hline $\begin{array}{l}\text { Check } \\
\text { evaluation }\end{array}$ & $\begin{array}{lr}\text { Prevention } & \text { of } \\
\text { mistakes } & \text { consistently } \\
\text { by } & \text { exchanging } \\
\text { greetings } & \text { between } \\
\text { teachers } & \text { and } \\
\text { employees } & \end{array}$ \\
\hline $\begin{array}{l}\text { Actions } \\
\text { follow-up }\end{array}$ & $\begin{array}{l}\text { Implement } \\
\text { continuous } \\
\text { improvement as a } \\
\text { routine activity }\end{array}$ \\
\hline
\end{tabular}

The Head of Human Resources at SMK Miftahul Huda Ngroto (2020), revealed that the Miftahul Huda Vocational School before carrying out the empowerment carried out planning which included an analysis of the needs of educators and educational personnel who had qualifications, certain specifications needed by the institution. This needs to be done as an effort to determine the strengths and weaknesses of the school's human resources, what needs the school needs, and to analyze what the lacks are so that improvements can be made. 
Through empowerment with a combination of TQM, institutions are able to obtain and find the right people to carry out the tasks required by schools according to their competencies and expertise so that human resource empowerment activities will run systematically to obtain superior and quality human resources.

The application of total quality management has an influence on human resource development. This influence is related to the role of employees or human resources in showing their performance through persistence in building creativity, sincerity in running the program, as well as the ability to develop themselves, confidence and the benefits of integrated quality management. In addition, the principal plays an active role, is open, indifferent, close to members of the organization and has leadership qualities (Syadzili, 2019). In improving the quality of a set of concepts or principles of integration between all sections or departments in school (Mulyadi., 1998). Therefore, all members must feel they have and are involved in running the existing system in educational institutions according to the guidelines for empowering human resources.

Human resources are a human investment movement. Human investment as a long-term educational effort to produce human resources (Almasri, 2016). Human resource development is not an easy problem because it requires thought, systematic and serious action. In addition, human resource management (HR) is needed in order to realize activities in educational institutions, which are included in the RENSTRA (Strategic Plan), RENOP (Operational Plan), and school annual programs (Nuraeni., 2019). In other words, institutional investment (capacity building) is needed with a focus on changing the pattern of understanding (mind set) and changes in work culture (institutional/work culture) among the people involved in it, especially those in managerial positions (Nilawati., 2015).

Islam also encourages development of human resources through training of employees with the aim of developing competencies and abilities so that they can carry out their job responsibilities. Professional human resources are human resources who are kafa'ah (have expertise), trustworthy (trustworthy), and charity (have a high work ethic). Therefore, guidance and development is needed that is based on three aspects, namely (1) syahsiyyah Islamiyah (Islamic personality), (2) skills or abilities and skills, (3) leadership and teamwork (M. Nazar Almasri., n.d.). 
Through this, the empowerment of human resources in educational institutions can increase the contribution of human resources to the organization in order to achieve the productivity of educational institutions (Widiansyah, 2018). Thus, the management of human resources that is appropriate can also achieve the organization's vision and mission effectively and efficiently.

\section{CONCLUSION}

Empowerment of human resources through total quality management, (TQM) always holds the principle of continuous improvement and customer orientation. The characteristics of the implementation of total quality management in human resource development focus on continuous empowerment. Empowerment that is carried out is by forming a quality assurance team consisting of 10 members as control and supervision of the course of the education process. The quality assurance team also participates in empowering existing human resources, this empowerment consists of three stages, first, the awareness stage, the second the capability transformation stage, and third, the intellectual development stage. The technique of empowerment stages which is implemented with total quality management at SMK Miftahul Huda Ngroto, namely by quality assurance consisting of Plan, Do, Checks, and Action. The implementation of this guarantee shows a significant increase in quality. Namely the success of SMK Miftahul Huda in administering education that is able to obtain superior accreditation, as well as outstanding graduates, and of course the form of quality, namely due to customer satisfaction which is marked by the increasing number of students attending SMK Miftahul Huda Ngroto, Grobogan.

The success of SMK Miftahul Huda Ngroto, Grobogan is made possible because of the interaction between teachers and students at the Islamic boarding school continuously every day so that even outside of school there is still control over the empowerment of existing human resources. The Islamic boarding school regulates attachment for all elements, between students, teachers, and managers of SMK Mifatahul Huda. In contrast to schools, it is generally limited to interactions at school.

Through the results of the conclusions discussed above, the researcher only discusses the quality of schools through a planned system in order to improve the quality of schools through existing human resources, namely teachers, students and managers. Suggestions for further researchers to be able to discuss other topics such as school management or 
in terms of infrastructure through total quality management.

\section{REFERENCES}

Abdullah. (n.d.). Strategi Pengembangan Mutu Sumberdaya Guru Miss Putri Sukorejo. JPII, 1(2), 161.

Almasri, M. N. (2016). Manajemen Sumber Daya Manusia: Implementasi dalam Pendidikan Islam. Kutubkhanab: Jurnal Penelitian Sosial Keagamaan., 19.(2.), 133-151.

Ambar Teguh, S. (2004). Kemitraan dan Model-Model Pemberdayaan. Graha Ilmu.

Anwar, K. (n.d.). Peranan penjaminan Mutu Pendidikan Dalam Meningkatkan Mutu Pendidikan Di Madrasah. 1(1), 49.

Budi. (2015). Profil SMK miftahul Huda Ngroto Grobogan. Https://Laduni.Id/Post/Amp/547 80/Smk-Miftahul-Huda-NgrotoGrobogan.

Buniarto. (2015). Penerapan Total Quality Management dalam Peningkatan Sumber Daya Manusia. Akademika, 13(2), 53-60.

Cahyo, A. N. (2017). Manajemen Sumber Daya Manusia (SDM) Pendidikan dalam Meningkatkan Daya Saing SDIT Ar-Rahmah Pacitan. Muslim Heritage., 1(2), 263.
Chairul Muhammad. (n.d.). Pemberdayaan Masyarakat Dalam Pengembangan Objek Wisata Greencanyon Sungai Gethuk di Desa Socokangsi, Jatinom, klaten.

Daniel C Kambay. (2004). Manajemen Kualitas Total dalam pendidikan (terjemah Buku Total Quality Management, Edward dan Sallis). Pascasarjana Universitas Manado. Deni. (n.d.). Operator TU SMK Miftabul Huda Ngroto, Grobogan.

Djam'an Satori. (2008). Profesi Keguruan. Penerbit Universitas Terbuka.

Edwin A. B. (n.d.). Penerapan Total Quality Management Dalam Meningkatkan Sumberdaya Manusia. Akademika., 13(2).

Fandy Tjiptono. (2001). Prinsip-Prinsip Total Quality Service. Andi Offset.

Hanik, U. (2011). Implementasi Total Quality Management (TQM) dalam Peningkatan Kualitas Pendidikan (Cet. 1). RaSAIL Media Grup.

Hijrawan, R. (2019). Pengembangan Manajemen Sumber Daya Manusia berbasis TQM di Madrasah Aliyah Nurul Ummah Kota Gede Yogyakarta. Al-Fabim: Jurnal Manajemen Pendidikan Islam., 1.(2.), 109-134. 
Ismail, S., Zahrudin, M., Ruswandi, U., \& Erihadiana, E. (2020). The Competence of Millennial Islamic Education Teachers in Facing The Challenges of Industrial Revolution. Ną̧hruna: Jurnal Pendidikan Islam, 3(3), 389-405.

https://doi.org/10.31538/nzh.v3i3. 823

Lexy J. Moleong. (2014). Metodologi Penelitian Kualitatif. Remaja Rosda Karya.

M Kadarisman. (2006). Manajemen Sumber Daya Manusia. Salemba Empat.

M. Nazar Almasri. (n.d.). Manajemen Sumber Daya Manusia: Implementasi dalam Pendidikan Islam. Jurnal Penelitian Social Keagamaan., 19.(2.), 135.

Muhammad Najib. (2020). Kabag Penjaminan Mutu SMK Miftabul Huda.

Mulyadi. (1998). Total Quality Mulyadi, Management. (Jilid Pert). Penerbit Aditya Media.

Muzayyin Arifin. (2011). Kapita Selekta Pendidikan Islam. Bumi Aksara.

Nilawati. (2015). Pengembangan Sumber Daya Manusia Dalam Pelaksanaan Sistem Penjaminan Mutu Pendidikan.

Notoatmodjo, S. (1992). Pengembangan Sumber Daya Manusia. Rineka Cipta.
Nuraeni. (2019). Manajemen Sumber Daya Manusia Lembaga Pendidikan. Jurnal Idaarah., 3.(1.), 124-137.

Nurulloh, A., Aprilianto, A., Sirojuddin, A., \& Maarif, M. A. (2020). THE ROLE OF THE HEAD OF MADRASAH'S POLICY IN IMPROVING TEACHER PROFESSIONALISM. Nidhomul Haq: Jurnal Manajemen Pendidikan Islam, 5(3), 334-346. https://doi.org/10.31538/ndh.v5i3. 963

Purwaningsih. (2019). Implementasi Manajemen Sumber Daya Manusia Di Sma N 1 Kota Metro. 7.

Radit Hijrawan. (n.d.). Pengembangan Manajemen Sumber Daya Manusia Berbasis Total Quality Manajemen di Madrasah Aliyah Nurul Ummah Kotagede Yogyakarta. Al Fabim, 2(1).

Ridwan Abdullah Sani dkk. (2015). Penjaminan Mutu Sekolah. Bumi Aksara.

Rifka Arfeinia dkk. (2020). Penerapan TQM Pada Lembaga Pendidikan Islam Dalam Perspektif Konsep Edward Deming Dan Joseph Juran. Institute PTIQ.

Rokhman., W. (2003). Pemberdayaan Dan Komitmen, Upaya Mencapai Kesuksesan 
Organisasi Dalam Menghadapai

Persaingan Global. Amara Books.

Rushaedi Thahari. (2018). Pengaruh Implementasi Total Quality

Management (TQM) Dalam

Meningkatkan Kinerja Elemen

Sumber Daya Manusia. INOVBIS., 6., 176-182.

Saril. (n.d.). Total Quality Management (Tqm)

Sebagai Wujud Peningkatan Mutu

Pendidikan. 9.(2.).

Septiadi, W. (2019). Tinjauan Total Quality

Management (TQM) Pada Lembaga

Pendidikan Islam. Nidhomul Haq:

Jurnal Manajemen Pendidikan Islam,

4(1), 34-51.

https://doi.org/10.31538/ndh.v4i1. 105

Soewadji Jusuf. (2012). Pengantar Metodologi

Penelitian. Mitra Wacana Media.

Sugiyono. (2013). Metode Penelitian

Pendidikan: Pendektan Kualitatif, dan R\&D. Al-Fabeta.

Sugiyono. (2017). Metode Penelitian Kuantitatif,

Kualitatif, dan R\&D. Alfabeta.

Suharsimi Arikunto. (2010). Prosedur

Penelitian Suatu Pendekatan Praktik.

Rheneka Cipta.

Suhermanto, S., Anshari, A. (2018).

Implementasi TQM terhadap Mutu

Institusi dalam Lembaga

Pendidikan. Al-Tanæim: Jurnal
Manajemen Pendidikan Islam., 2.(1.), 107-113.

Supardi, E. (2018). Total Quality Management (TQM) dalam Pemberdayaan Sumber Daya Manusia.

Syadzili, M. F. R. (2019). Polarisasi Tahapan Kepemimpinan Transformatif Pendidikan Islam. Al-Tanzim: Jurnal Manajemen Pendidikan Islam., 3.(1), 55.

Syam Syam, A. R. (2017). Konsep Kepemimpinan Bermutu dalam Pendidikan Islam. Al-Ta'dib., 12.(2), 49-69.

Taufiq Rahman. (2013). Implementasi TQM Manajemen Kualitas.

Veithzal Rival Zainal, Dkk. (2016). Islamic quality Education Management. PT Gramedia Pustaka Utama.

Warti'ah, W. (2020). The Implementation of Madrasa Culture in Building Students' Character. Nazhbruna: Jurnal Pendidikan Islam, 3(2), 247259. https://doi.org/10.31538/nzh.v3i2. 583

Wibowo. (2007). Manajemen Kerja. PT. Raja Grafindo Persada.

Widiansyah. (2018). Peranan Sumber Daya Pendidikan sebagai Faktor Penentu dalam Manajemen Sistem Pendidikan. Cakrawala, 299-234. 
Nidhomul Haq, Vol 6, Issue 1, 2021

Yuda Sulistyo. (n.d.). Kepala Sekolah SMK

Miftabul Huda Ngroto, Grobogan. 